\title{
Itinéraire de Napoléon au jour le jour, 1769-1821
}

Josiane Bourguet-Rouveyre

\section{(2) OpenEdition}

\section{Journals}

Édition électronique

URL : https://journals.openedition.org/ahrf/1965

DOI : 10.4000/ahrf.1965

ISSN : 1952-403X

Éditeur :

Armand Colin, Société des études robespierristes

Édition imprimée

Date de publication : 1 décembre 2005

Pagination : 263

ISSN : 0003-4436

Référence électronique

Josiane Bourquet-Rouveyre, «Itinéraire de Napoléon au jour le jour, 1769-1821 », Annales historiques de la Révolution française [En ligne], 342 I octobre-décembre 2005, mis en ligne le 05 avril 2006, consulté le 23 avril 2022. URL : http://journals.openedition.org/ahrf/1965 ; DOI : https://doi.org/10.4000/ahrf. 1965

Ce document a été généré automatiquement le 23 avril 2022

Tous droits réservés 


\title{
Itinéraire de Napoléon au jour le jour, 1769-1821
}

\author{
Josiane Bourguet-Rouveyre
}

\section{RÉFÉRENCE}

Jean TULARD et Louis GARROS, Itinéraire de Napoléon au jour le jour, 1769-1821, nouvelle édition revue et corrigée par Jean Tulard et Jacques Jourquin, Tallandier, Bibliothèque napoléonienne, 2002, 666 p., ISBN 2-84734-016-5, $25 €$

1 Il s'agit d'une nouvelle édition de l'itinéraire de Napoléon précédemment publié aux éditions Tallandier en 1992. Cette initiative est un élément de la vaste entreprise d'authentification des actes et de la correspondance de cette personnalité historique hors du commun, qui a suscité, comme on le sait, une immense littérature de valeur inégale. En 2001, dans un souci de mise au point scientifique, Jean Tulard a présenté et annoté les trois volumes de l'œuvre littéraire et des écrits militaires de Napoléon Bonaparte. Depuis, la Fondation Napoléon, présidée par Thierry Lentz, s'est lancée dans l'ambitieuse entreprise de publier une édition exhaustive de sa correspondance, débarrassée des scories et comblant lacunes et silences de l'édition du Second Empire, qui faisait jusqu'alors référence. Le premier volume est paru récemment. Dans le cas présent, les auteurs se sont attachés à enrichir encore l'itinéraire que Louis Garros avait fait paraître en 1947. Il ne s'agit pas d'une chronologie commentée de la Révolution et de l'Empire, mais d'une recension méticuleuse et précisément datée des lieux visités par Napoléon et des actes qu'il y a accomplis, qu'il s'agisse du domaine militaire ou de l'œuvre civile. L'ouvrage est complété par un index des lieux qui en facilite le maniement. C'est donc un instrument de travail utile pouvant satisfaire les besoins de tout amateur fasciné par le personnage, mais présentant aussi des références sérieuses à l'historien. 